\title{
Sciendo
}

Janusz Myszczyszyn (West Pomeranian University of Technology

in Szczecin, Szczecin)

ORCID: 0000-0001-9578-5741

jmyszczyszyn@zut.edu.pl

\section{DEVELOPMENT OF TRANSPORT AS A FACTOR OF THE ECONOMIC MIRACLE (WIRTSCHAFTSWUNDER) OF WEST GERMANY}

\begin{abstract}
The post-war economic policy of West Germany (FRG) is largely associated with the so-called economic miracle (German: Wirtschaftswunder) and therefore its causes are the subject of many different analyzes. They include the correlation between the rate of economic growth in Germany and the development and transport potential of transport, including rail and road-car transport. This position prompted the author to try to search for long-term interdependencies and thus verify the thesis using the analysis of time series (1950-1989) available for West Germany and using original econometric methods in this field, e.g. unit root test to determine the stationarity and the Engle-Granger cointegration test.

In addition to the introduction, the article consists of three parts and conclusions. The broadest one includes the description of the assumptions and stages of the research procedure and its results, both on the empirical and methodological level. It is based on synthetic theoretical foundations presented on the basis of a review of international literature on the subject and review of the essence of the German economic miracle and the main trends in changes in the field of economic growth and transport development in Germany after World War II. The research presented in this way fits into the principles of the new economic history paradigm, which is still not very popular in Europe.
\end{abstract}

Keywords: German economic miracle, economic growth and transport development in Germany (1950-1989), the unit root studies, Engle-Granger cointegration test, social market economy, paradigm of the New Economic History (NEH)

doi: $10.2478 /$ sho-2021-0008 


\section{INTRODUCTION}

The revolution that took place in European transport in the nineteenth century, which had its source in the English technical revolution, ran simultaneously with the construction of nation states. A special role in this process was played by the development of new forms of transport, which were initially railways, and in the period after World War II, the dynamic development of road and air transport.

Before the expansion of the railways, underdeveloped and ineffective land transport was not able to respond to the increasing demand from the developing economy (industrialization process). Therefore, it is not without reason that railways are commonly regarded in world literature, including German-language ones, as the leading sector of economic development [Ziegler D. 1996; 94, Myszczyszyn J. 2013]. In the first decades of the nineteenth century, in the conditions of the political breakdown and economic diversification of German states, the expansion of the railways played an important role in the process of economic integration of Germany and strengthening its position on the international arena.

The progressive development of the automotive industry, especially after the end of World War II, contributed to the collapse of the volume of rail freight and passenger transport. At the same time, the establishment of new borders, including the division of Germany into two states, with different political and economic systems, resulted in the need for a different approach to the development of communication infrastructure, including the railway infrastructure.

In this article, the author developed his previous research on the assessment of the impact of transport, including railways, on the economic growth of Germany in the period up to World War I [Myszczyszyn J. 2019] by looking for patterns of economic growth in the Federal Republic of Germany, starting in the 1950s to the period preceding the reunification of Germany, i.e. in the period when the so-called economic miracle or the Miracle on the Rhine (Wirtschaftswunder) occured, which became one of the key issues in German economic history after World War II. Already in the 1950s, the reconstructing German economy reached its level from before the outbreak of World War II, and the level of global product and per capita was rising rapidly.

Although this issue is richly presented in world literature, both by economists and historians, the development of research methods, includ- 
ing econometric tools, certainly makes it possible to enrich these analyzes and verify some of them as well.

The abundant literature, including the available statistical data, prompted the author to use these tools and set several research goals for this article. They were:

1) identification of the causality and its direction between the level of economic growth in Germany and rail and road freight,

2) analysis of changes occurring in the German railways, resulting from the division of Germany after World War II and the development of road transport,

3) assessment of the pace of economic growth in Germany and the economic policy pursued,

4) signaling trends and prospects for further development of transport, including railways.

The previously published results of research using traditional econometric modeling (interdependent equations) confirmed that there were relationships (including feedback) between the economic growth of the Second German Reich and rail transport expressed in tonne kilometers (tkm) and vice versa [Myszczyszyn J. 2019].

Making the assumptions for the Engle-Granger cointegration test, it was investigated whether the interdependencies between economic growth and the potential of transport, including railways, and the results of foreign trade were of a long-term nature. Statistical data were used on an annual basis from statistical yearly (1950-1990).

\section{RELATIONSHIP BETWEEN ECONOMIC GROWTH AND TRANSPORT - THE REVIEW OF SCHOLARSHIP}

Transport, which is one of the important factors of economic development, has been the subject of many studies, among which a special role is assigned to the analysis of cause and effect relationships between the demand for transport and economic growth. The results of some empirical studies concern the assessment of the impact of transport infrastructure on economic growth. The research concerns various countries, economic areas, periods and types of transport, hence it is justified to refer to these studies. Germany, being a country poor in mineral resources, has long perceived efficient transport as one of the key factors of competitive advantage and building social welfare [Hartwig K.H. et al. 2008: 18-20]. 
According to Riadh Harizi and Raaf M'raïhi, investments in transport infrastructure generate two types of effects:

- direct, especially in terms of improving accessibility, including on the improvement of mobility, i.e. the expansion and improvement of transport, have a long-term impact on economic growth, therefore any increase requires the development of transport, without a well-developed transport, e.g. trade does not develop;

- indirect, related to multiplier effects and having a short-term impact, e.g. the expansion of transport infrastructure led to an increase in public works financed by the state and the creation of additional jobs and an increase in income at the local level, thus stimulating economic growth. Hence, the development of transport is considered an integral component of the production and consumption cycle, which also has a positive impact on the development of the business sector [Harizi R., M'raïhi R. 2014].

Andreas Knie quotes the indicators of transport flexibility and states that the study of the GDP level cannot be performed without taking into account transport [Knie A. 2007: 48], because the analysis of the period 1980-2006 shows that an increase in real GDP by 1\% led to an increase in transport capacity passenger by $1.3 \%$. Even stronger was the impact of GDP on the growth of the freight transport potential and amounted to $2.2 \%$. It has been carefully estimated that a $1 \%$ increase in government infrastructure investment would result in a long-term increase in real GDP of at least $0.1 \%$ [Suntum U. et al. 2008: 77 et seq.]. The authors add that the lack of necessary investments in the construction or expansion of transport infrastructure leads to the formation of bottlenecks and overload phenomena that increase transport costs and affect the social division of labor.

There is no doubt that modeling long-term relations is of great importance in economics, especially in relation to such a macroeconomic problem as economic growth. The study of cointegration serves to capture the long-term equilibrium (dependence), while the study of the interdependence between the first differences is used to study the short-term dynamics [Enders W. 2010, Kusideł E. 2001].

This is reflected in research devoted to the search for causality in transport, which uses: VAR (Vector Autoregressive Models), VECM (Vector Error Correction Model) models, as well as IRF (Impulse Response Function), including Engle-Grander and Johansen causality tests.

For example, Peter Groote, Jan Jacobs, Jan-Egbert Sturm performed the Granger causality test for a multi-equation model using the VAR method 
for the Netherlands (1853-1913). They stated that infrastructure investments in the transport and communication sector positively affect GDP growth, but the GDP growth itself negatively affects the level of investments in the transport and communication sector [Groote P., et al. 1999].

Research by Johannes Fedderke, Peter Perkins, and John Luiz confirmed the two-way causality between various views of economic infrastructure, including transport and communication, and the economic growth of South Africa in the years 1875-2001 [Fedderke J.W. 2006].

William Cullison analyzed the impact of government investment in both physical and human capital on economic growth. He used the Gran ger causality test to establish the relationship between different types of government spending and economic growth in the US between 1955 and 1992. The results of these studies did not confirm a causal relationship between expenditure on transport, including rail, air transport and highway construction, and economic growth [Cullison W.E. 1993].

Research by Mudit Kulshreshth, Barnali Nag and Mukul Kulshreshth, devoted to the study of the relationship between GDP per capita and inland transport per capita (Mg) for 15 EU countries in 1970-2008 observed a two-way causality between GDP and inland transport in the case of 8 countries with the highest level of GDP per capita [Kulshreshtha M., et al. 2001: 29-45].

Research by R. Harizi and R. M'raïhi on Burkina Faso, one of the poorest countries in the world, using the VAR model and the Vector Error Correction Model (VECM) shows many interactions between GDP, the transport system and the population. They show that in the years 19602008 there were interactions in the medium and long term, known as the "snowball" [Harizi R., M'raïhi R. 2014].

The use of the VAR model in the study of the demand for freight transport by Indian railways in the years 1960-1995 showed that there is a longterm two-way relationship between the demand for freight transport and the level of GDP [Beyzatlar M.A. et al. 2012: 1-17].

Empirical studies on the economic effects of infrastructure in Germany provide information on short-term economic effects. Both short-term impulses and long-term growth effects have been presented by selected authors [Busch B., Klös H.P. 1995; Suntum U. et al. 2008; Bom P.R.D., Ligthart J.E. 2008].

Urlich Suntum (and others) already in the introduction estimate that the well-developed infrastructure in Germany was an important element in economic competition with other countries, at the same time they warn 
that, in the face of various kinds of omissions, including political ones, Germany may lose this advantage [Suntum et al., 2008].

In his fundamental research, David Alan Aschauer supports the socalled Public Capital Hypothesis, according to which the decline in US public infrastructure investment between 1949 and 1985 contributed to weaker economic growth. [Aschauer D.A. 1989]. For example, a 1\% increase in real GDP led to a 1.3\% increase in passenger transport (19802006), and in freight, the increase was as high as 2.2\%. [Knie A. 2007]. The results of Pedro Bom and Jenny Ligthart's research on the impact of infrastructure capital growth on economic growth show a long-term relationship if infrastructure capital increased by 1\%, real GDP increased by 0.08\%. [Bom P.R.D., Ligthart J.E. 2008].

Most studies, such as the above-mentioned research by D. A. Aschauer, show the positive impact of infrastructure development on economic growth. There are also studies that prove that transport (especially traditional transport) can have negative effects, because it is associated with increased greenhouse gas emissions, and thus weakens economic growth [Li F., 2014; Shafique M. et al. 2020]. Various conclusions from the conducted research may result from differences in the scope of: the models used, their specifications, estimation methods, country (research area), observation period, etc.

In conclusion, various studies have proved or excluded the two-way relationship between economic growth and transport development, while demonstrating the usefulness of the cointegration test, including unit element tests. This is an argument that the analysis of such a relationship for Germany is scientifically important.

\section{ECONOMIC GROWTH AND DEVELOPMENT OF TRANSPORT IN WEST GERMANY AFTER THE SECOND WORLD WAR. THE GERMAN ECONOMIC MIRACLE}

The division of the territory of the Third German Reich after World War II, and the emergence of two separate states with different socio-economic systems functioning until the early 1990s, fundamentally influenced the dichotomy of economic policy, including the one aimed at the reconstruction and development of individual modes of transport [Stadelbauer J. 1994: 60]. 
In the period from the establishment and expansion of the railway network in the German states and the later Second German Reich, until the end of World War II, connections in the west-east direction were particularly important, including the connections between the Ruhr and Berlin, the eastern Prussian provinces and the western part of the Reich [Myszczyszyn J. 2019]. It was justified both economically and politically, and resulted also from the system of navigable water networks. Under the conditions of Germany, the thesis about the enormous importance of railways is rightly emphasized, including the theory of leading sectors, formulated by Walt Whitman Rostov [Rostow W.W. 1960: 4-16].

Just before the outbreak of World War I, the total length of the railway lines managed by the Deutsche Reichsbahn (DR) exceeded 62 thousand. $\mathrm{km}$. In 1924, DR was transformed into a joint-stock company, which was related to the war reparations imposed on Germany (Weimar Republic). During A. Hitler's dictatorship, DR was nationalized.

After the end of World War II, railways were a means of transport that could return to operation relatively quickly, but due to different political systems and the shape of borders, the north-south direction became the dominant direction in both countries. Large metropolitan centers located on the territory of Germany (the Ruhr area with Essen and Dortmund, the area of Düsseldorf-Koeln-Bonn, the area of Rhine-Main with Frankfurt, Hanover, Hamburg, Munich, and to a lesser extent Stuttgart and Nuremberg) became the basis for planning new high-speed lines (ICE). In the GDR, the north-south axis connecting the centers: Rostock through Berlin, the area of Leipzig-Halle and the cities of Thuringia and Saxony also dominated [Stadelbauer J. 1994: 61-2].

Figure 1 shows the changes in the length of railway lines and the number of wagons in Germany in 1950-1990. It shows the long-term tendency of the gradual reduction of the length of railway lines. While in 1950 the length of railway lines amounted to 36.9 thousand. km, in 1960 it dropped to 36 thousand. $\mathrm{km}, 10$ years later there were railway lines by 3 thous. km less, in 1980 the total length of the iron routes was 31.5 thousand. $\mathrm{km}$, and in 1989, 29.8 thous. $\mathrm{km}$.

In the analyzed period, the average annual decrease in the length of railway lines was recorded at the level of almost $0.3 \%$. This clearly proves that rail transport has been increasingly replaced by fast and dynamically developing road transport. The number of freight wagons fell from 236,000 to units (1950) to 231 thousand (1954), after which it increased even to 291,000. (1978). In the following years, there was a gradual decrease to the 


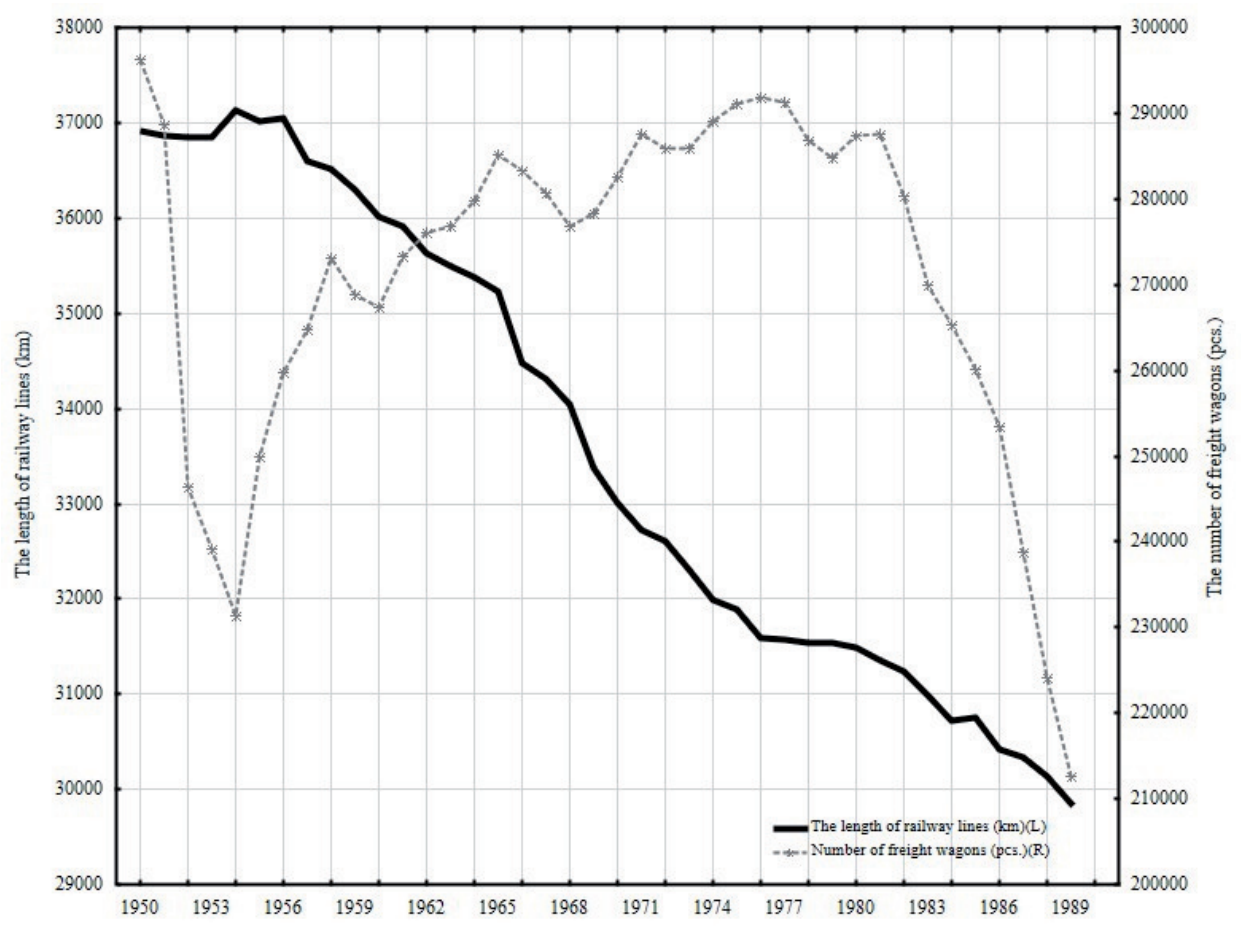

Figure 1. The length of railway lines in Germany $(\mathrm{km})$ against the number of freight wagons (pcs.) In the years 1950-1990

Source: Fremdling R. et al. [1995: 25, 27].

level of 212 thousand. units in 1989. The number of locomotives decreased just as quickly: from 14.8 thous. units (1950) up to 10.1 thous. (1980) and 8.8 thous. pieces before German reunification.

In 1950, 229.3 million $\mathrm{Mg}$ of goods was transported by rail, the weight increased to 327 million $\mathrm{Mg}$ (1960) and 365.5 million $\mathrm{Mg}$ (1970). In the next decade, the interest in rail transport decreased significantly, and the weight of transported goods reached 331 million $\mathrm{Mg}$ (1980), while in 1989 it dropped to 286.5 million $\mathrm{Mg}$.

In the 1960s, the rapidly developing road transport recorded only 98.7 million $\mathrm{Mg}$ of transported goods, in 1970 this weight increased to 164 million $\mathrm{Mg}$, while in 1980 it was already 2.5 billion $\mathrm{Mg}$, and in 1989 it was 2.7 billion $\mathrm{Mg}$.

Returning to the post-war times, the factors influencing the pace and scale of the reconstruction of the fallen Nazi Reich were: 
- currency reform carried out by L. Erhard, which enabled quick integration with the world market;

- restoring the importance of exports and regaining the shine for Made in Germany goods;

- technological development, rapid increase in productivity and work efficiency.

The import of missing raw materials (including fertilizers, feed) and goods enabled the economic recovery, while the supply of capital goods was not without significance. Industrial production increased rapidly, reaching an increase of $13 \%$ in the period 1946-1950.

In the face of crises afflicting the economies of capitalist countries, the pressure to increase investment in infrastructure was a classic economic policy approach, as an increase in government investment can contribute to the growth of the global product. Infrastructure also contributes to private sector production, as some goods can only be produced if adequate infrastructure is available. This applies, for example, to transport networks and energy supply. In western Germany, the gross government investment in infrastructure increased from EUR 15 billion to EUR 25 billion in the 1970s compared to the early 1960s. First of all, it was a consequence of the conducted economic policy in the face of two oil crises. From the mid-1980s, a decline in investments was observed, and only at the beginning of the 1990s, the level of expenditure of EUR 26 billion was achieved [Bardt H. et al. 2014].

The American economic aid program, commonly known as the Marshall Plan, is often presented in Polish literature as a serious determinant of German economic growth. The fact is that West Germany was the recipient of this aid; of the amount allocated to 1951 USD 13.5 billion, they gained over 10\% [Skodlarski J. 2012, 331, Berger H., Ritschl A. 1995: 474; Borchardt K., Buchheim C. 1987, Buchheim C. 1990]. Funds under this plan were transferred in the years 1948-1952 for a total amount of USD 1.678 billion [Deutsches Geld... 1976: 323, 341]. However, the economic effects of this aid should be approached with great caution, pointing to various controversies, including the scarcity of funds in relation to the enormity of needs. Heinz-Peter Spahn points out that the measures under the Marshall Plan accounted for only about $2 \%$ of GDP and actually contributed to securing real incomes of the population while allowing for the financing of excess imports while concealing the unstable external economic situation of West Germany. He also emphasizes that German monetary 
policy was more expansionary, although it was ultimately impossible to avoid the crisis in the balance of payments [Spahn H.P. 1991: 74].

It cannot be denied that the funds from the Marshall Plan were spent on investment purposes, e.g. in 1949 21.8\% (mainly in the mining, energy sector, transport (railways)), although this percentage decreased rapidly: to 14, 5\% in 1950, 7\% in 1951, 4.8\% in 1952 [Baumgart E.R. 1961: 47]. The so-called Rekonstruktionsthese assumes that the European Recovery Program (ERP) was late, and the impact of the Marshall Plan on the German economy was limited. In the 1950s, most European countries saw rapid economic growth, regardless of the liberal or even centrally planned policies [Berger H., Ritschl A. 1995: 474, 477 et seq.].

The thesis on economic reconstruction and rebuilding, explaining the German economic miracle, places the focus on the development of institutions and organizations that basically shaped the economic life of the Weimar Republic, but whose roots go back to the times of the Second German Reich. It remains important to limit market coordination through active state policy in the sphere of employment [Abelshauser W. 2011(b); Abelshauser W. 2004].

On the other hand, it was in the interest of the United States that in the short term, while rebuilding its economy, Germany would become the main supplier of capital goods for other countries, which in the long term was to lead to independence from American funds and to close the dollar gap in trade with the United States. [Gimbel J., 1976; Milward A.S., 1984, Knapp M. 1977].

The revision of views on the impact of the Marshall Plan and Erhard's reform was carried out by Franz Jánossy, then by Werner Abelshauser, in which, inter alia, they refer to the hypothesis of "catching-up" growth by Moses Abramowicz. M. Abramowicz assumed that the economic success of Western European countries lay in the ability to import and implement technologies from the USA. German researchers conclude that external aid, including the reconstruction plan, like Erhard's reforms, took place at a time when the reconstruction process was already underway [Jánossy F. 1966; Dumke R. 1990; Abramovitz M. 1986].

In principle, it can be concluded that the processes of economic recovery, being exogenous in nature, depended on the time when the economy managed to overcome bottlenecks in the destroyed transport infrastructure. In this context, the impact of the Marshall Plan seems to be of secondary importance. 
Notwithstanding the above controversy, the economic boom in West Germany since 1950 can be seen as an example of export-oriented economic growth. This does not mean the problems that appeared in the early 1950 s, such as the high unemployment rate $(11 \%$ compared to e.g. $1.3 \%$ in Great Britain) in the aforementioned crisis of the balance of payments.

The real economic miracle of post-war Germany, however, was to break the unstable process of economic growth in the early 1950s with a serious balance of payments crisis and practical insolvency in the international arena. Protectionist policies, including the introduction of customs duties on imported goods and differentiating them according to the degree of processing, contributed to the promotion of domestic production. The restrictive monetary policy pursued (an increase in interest rates) limited domestic demand, including imports. Thanks to the increase in exports (including the boom in the Korean economy), Germany managed to balance the trade balance [Spahn H.P. 1991].

The pace of economic growth in the 1950s was impressive; it amounted to over $8 \%$ per year throughout the decade. Already in the early 1960s, West Germany was considered the largest and most influential economy in Europe [Eichengreen B., Ritschl A. 2008: 2]. In their research, Barry Eichengreen and Albrecht Ritschl provide the following three possible scenarios for Germany's economic miracle in the 1950s:

1) rapid economic growth in the context of catching up in productivity and convergence with other economies;

2) institutional changes, including profound changes in socio-economic institutions after World War II conducive to faster development;

3) negative impact of the output shock in the last phase of the war and immediately after its end, which should be understood as short-term fluctuations and a return to the path of long-term growth [Abelshauser W. 1981a; Abelshauser W. 1981b; Dumke R. 1990: 52, 451-91, Borchardt K. 1976].

In the conclusions, based on the analysis of the assumptions for the classical school, as well as institutionalism, they emphasize that factor 3) was the most important, i.e. after the economic collapse in the post-war period, the country still had the institutional ability to restore a high level of production capacity.

Note that the central bank of the Federal Republic of Germany (initially the Bank of German Länder (Bank deutscher Länder (BdL)), and from 1957 the Bundesbank (Die deutsche Bundesbank) introduced a new currency, the German mark (DM), and in the 1950s pursued a monetary 
policy in line with the mercantilist doctrine. Currency reform was an important prerequisite for the birth of the social market economy. With the introduction of the DM, most prices in the economy were freed, reducing the importance of the black market. Much earlier John Stuart Mill indicated that after the crisis, currency reform can effectively affect economic growth [Mill J.S. 1924: 112].

In empirical research on Germany's growth, economic policy, and in particular foreign trade policy, are treated equally as institutional factors and are perceived as having a similar importance. The liquidation of import quotas led to a trade deficit; Demand for imported goods grew rapidly, and exports remained low under a liberal trade policy. In 1950, the value of German imports was 11.35 billion DM, while exports were only DM 8.36 billion. As Werner Abelshauser adds, about 18\% of German imports had to be financial means available under the Marshall Plan [Abelshauser W. 2011: 224].

In the period 1950-1960, the structure of German foreign trade changed significantly. While in 1950 the largest percentage of imports were agricultural products $40.9 \%$, 29.6\% raw materials necessary for production, semi-finished products $13.7 \%$, and finished products $12.6 \%$, ten years later respectively: import of agricultural products dropped to $26.3 \%$, raw materials to $21.7 \%$, semi-finished products $18.9 \%$, finished products $32.2 \%$. In the case of exports in 1950, the export of finished products was dominant and amounted to $64.9 \%$, which was quite a low percentage compared to the pre-war years (even $80 \%$ ), semi-finished products $18.8 \%$, raw materials $14 \%$, while the export of agricultural products accounted for only $2,3 \%$. In 1960, exports of finished products amounted to $82.4 \%$, semi-finished products dropped to $10.4 \%$, raw materials to $4.6 \%$, exports of agricultural products remained unchanged.

The development of the German economy, with the deliberate pursuit of pro-export monetary policy (weakening the DM), contributed to a surplus of exports over imports. In 1950, imports exceeded the total foreign turnover by $13.6 \%$, and in 1960 export exceeded the total turnover by $5.4 \%$. The percentage of the value of exports as part of the national product gradually increased. For example, in the years 1910-1913, in the conditions of the generally open to foreign trade of the Second German Reich, exports amounted to about $17.5 \%$ of the net national product (NNP), the new idea of self-sufficiency of the Third Reich led to a decrease in the value of exports to $6 \%(1935 / 1938)$. While after the establishment of Germany in 1950, the percentage of the export value was only $0.8 \%$, in 1960 it already 
exceeded the level from before the First World War (19\%), and ten years later it increased to $21 \%$, reaching the level of $24.7 \%$. In 1980, this percentage continued to increase and amounted to $26.4 \%$, while it decreased to $23.5 \%$ in the mid-1980s.

On July 23, 1952, the treaty on the establishment of the European Coal and Steel Community was signed, although duties on raw materials (including coal and coke) played a minor role after the war, an important effect was the abolition of national discrimination in transport. The above synthetic review confirms that the economic success achieved by the Federal Republic of Germany justifies the statement that the economy played a special role in the post-war history of this country [Abelshauser W. 2011: 11]. Nevertheless, the search for factors of this growth can be noticed, apart from the commonly known factors, such as the external assistance of the Allies, including the USA, or Erhard's reforms, referred to as the social market economy (Soziale Marktwirtschaft).

It seems that the greatest influence on the economic policy of West Germany and the economic miracle [Kamińska K. 2018] was exerted by Keynesianism and ordoliberalism, as the choice of the so-called the third way, between liberalism and socialism [Röpke W. 1945]. Some authors, however, question the recognition of the views of ordoliberals and Erhard himself as the foundation of the German Wirtschaftswunder [Berghahn V. 1984; Nicholls A.J. 1990].

The explanation of the German economic miracle is certainly the institutional changes that led to the elimination of the collective search for high rents, creating room for rapid economic growth. Indeed, the German economy remained strictly regulated, following the regulatory model established in the interwar period.

\section{METHODS AND STAGES OF THE RESEARCH PROCEDURE AND THE RESULTS OF THE AUTHOR'S EMPIRICAL ANALYSIS}

In economic analyzes, there is a need to combine conclusions regarding short-term dynamics and long-term balance. The traditional approach to modeling short-run imbalance is based on a partial adjustment model, and its development is the error correction model (VECM), which takes into account imbalances in past periods [Maddala G.S. 2008: 322-27]. Long-term versions of economic models correspond to the stationary state 
[McAdam P. 1998, Granger C.W.J. 1991]. Taking into account the fact that time series for economic quantities are usually non-stationary, a particularly important task is to study their cointegration. The cointegration relationship equation can be used to present the state of long-term equilibrium. Co-integration is usually assessed using the Robert Engle-Clive Granger test or the Søren Johansen method [Johansen S. 1988: 231-54]. An advantage of the approach of R. Engle and C. Granger is its simplicity.

As already indicated, most of the variables used in economic models are characterized by non-stationary courses, which may lead to the establishment of apparent relations (apparent regression) and lead to erroneous conclusions. Formulated by C. Granger and developed by R. Engle and C. Granger, the cointegration theory eliminates the main obstacle in modeling non-stationary series [Granger C.W.J. 1981: 173-88; Engle R.F., Granger C.W.J. 1987: 251-76]. The author presented a broader description of these methods in earlier works [Myszczyszyn 2019, 2020].

According to the theory, two processes $y_{t}, x_{t}$ are cointegrated of degree $(\mathrm{d}, \mathrm{b}),\left(y_{t}, x_{t} \sim C I(d, b), d \geq b \geq 0\right)$, if:

- the degree of integration $d$ of both processes $\left(y_{t}, x_{t}\right)$ is the same;

- there is a linear combination of these processes $u_{t}=\beta_{t} x_{t}+y_{t^{\prime}}$ which is integrated of the degree $d-b$.

In view of the above, a necessary condition in the study of time series of economic quantities is to test the degree of integration of time series using the so-called unit root test. For the analyzed correlation, cointegration occurs if each of the time series $y_{t}$ and $y_{t}$ is integrated of the first degree, which we write symbolically I(1), i.e. the null hypothesis about the unit root is not rejected, and the remainder $u_{t}$ of the cointegrating equation are not integrated of the degree I(1), that is, the null hypothesis of the unit root is rejected. For this purpose, the following tests can be used, for example: Dickey-Fuller and Kwiatkowski-Philips-Schidt-Shin (KPSS) [Dickey D. A., Fuller W. 1979: 427-31].

The cointegration study was conducted for the following three groups of variables:

- Germany's economic growth,

- freight and passenger transport by rail ( $\mathrm{tkm})(\mathrm{Mg})$,

- export level (million DM).

In the case of the variables describing economic growth, the following were examined:

- GDP (GDP_C) in constant prices,

- GDP per capita (GDP_PC_C) in constant prices. 
With regard to freight and passenger transport by rail and road transport, the following variables were used:

- rail freight in million tkm (1_RF_tkm),

- passenger rail transport in million pkm (1_RP_pkm),

- rail freight in tonnes (1_RF_Mg),

- freight transport using road transport (1_CR_Mg).

With regard to foreign trade, the export level (1_Ex) was used.

At the initial stage of the analysis, the analyzed variables were logarithm [Marona B., Bieniek A. 2013: 333-350].

The research consisted of the following stages:

- unit root tests for the analyzed variables, determining the degree of integration,

- estimation of the cointegrating equation (Engle-Granger test) for integrated variables,

- testing the significance of assessments of the parameters of the cointegrating equation,

- determination of the residuals of the cointegrating equation,

- unit root test for the residuals of the cointegrating equation,

- analysis of the obtained results.

The research was conducted using the GRETL v. 2018a program.

\section{RESEARCH RESULTS}

At the initial stage, the analyzed variables were presented graphically (Fig. 2-4 logarithmic scale).

The 1950s were a time for West Germany in which the global product grew rapidly. The real annual GDP growth rate in the period 19501960 was $8.2 \%$, while the GDP per capita reached the average annual rate of $5.8 \%$. In this period, the rate of growth of industrial production was equally high, in 1951, compared to 1950, it increased by $18.7 \%$, while in the years 1953-1955 this increase oscillated between $10.2 \%$ and $14.8 \%$, a lower growth rate it took place in the second half of the $1950 \mathrm{~s}$, e.g. $6.1 \%$ in 1957 and 8.3\% in 1958. The lowest increase was recorded in 1959 and it was $2.6 \%$ compared to 1957 . The unemployment rate decreased gradually; while in 1950 it was $11 \%$, in 1960 it fell to just 1.3\%. Inflation in the 1950 s fell from $7.5 \%$ in 1951 to $1.1 \%$ in 1959. Public debt was only $20 \%$ of GDP.

In the 1960s (1960-1970), the average annual GDP growth rate was significantly lower and amounted to $5.1 \%$, similarly to GDP per capi- 


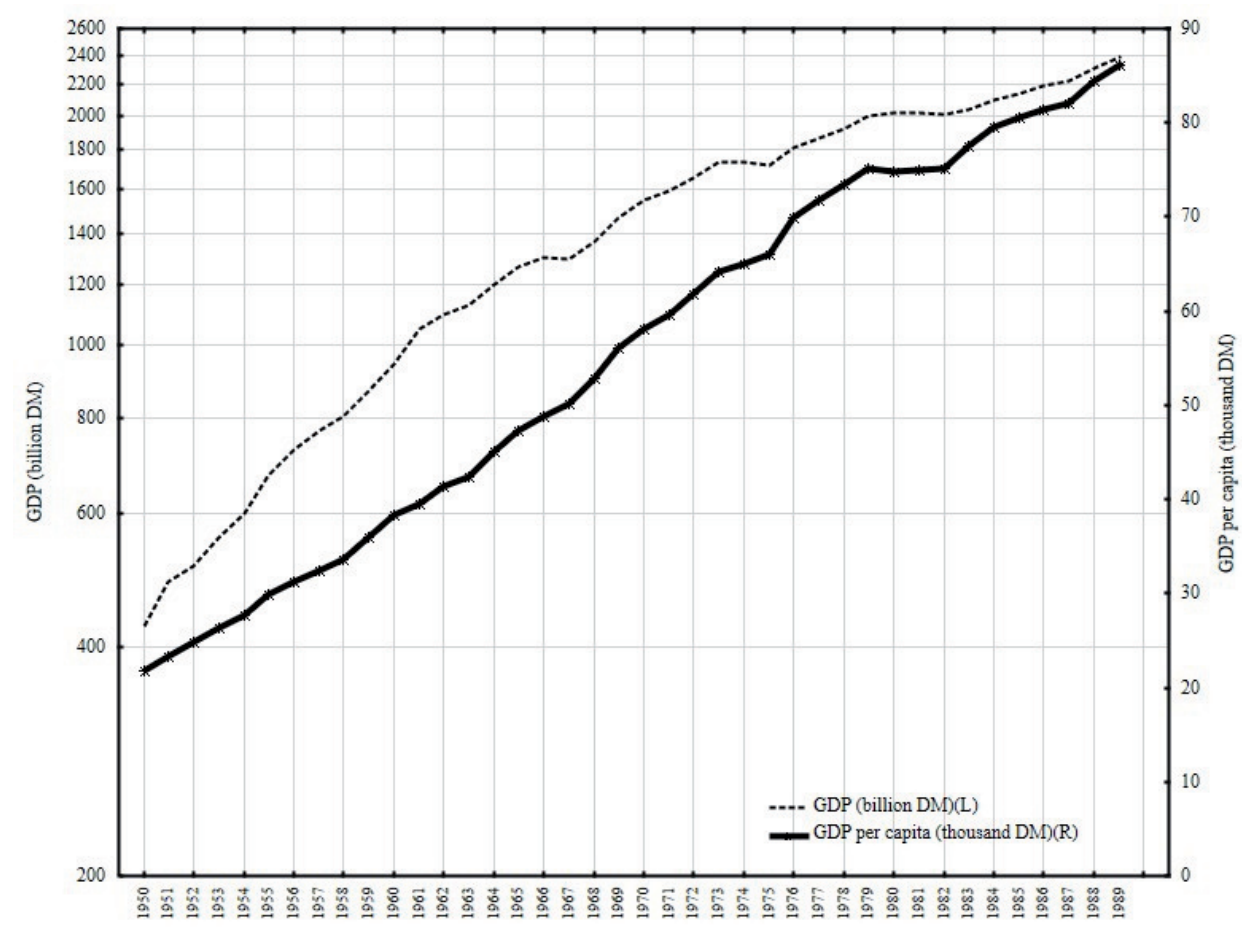

Figure 2. GDP (billion DM), GDP per capita (thousand DM) in constant prices (1950-1989) (logarithmic scale)

Source: own study based on: Statistisches Jahrbuch ... [1999: 667].

ta, which grew in real terms by $4.2 \%$. At constant prices, GDP per capita increased from 38.3 thousand. DM (1950) to 58.1 thousand DM. At that time, the pace of industrial production growth clearly decreased, reaching the level of $6.8 \%$ in $1961,8.1 \%$ in 1964 and dropping to $0.9 \%$ in 1966. It must be recognized that the situation on the labor market was still stable and the unemployment rate fell below $1 \%$, oscillating between $0.7-0.8 \%$. Unfortunately, the economy suffered from a labor shortage, and the low birth rate consequently led to an increase in production costs, which in turn had to translate into a lower growth rate of the global product. In 1966, the direction of fiscal policy was changed from expansive to restrictive. As a result of the impossibility of adopting the budget, Erhard's government resigned in 1966. With the appointment of the new government of Kurt Georg Kiesinger, the assumptions of greater state activity were adopted, in line with the assumptions of Keynesian policy, which resulted in a stabilization policy. In the years 1967-1982, there were two business cy- 


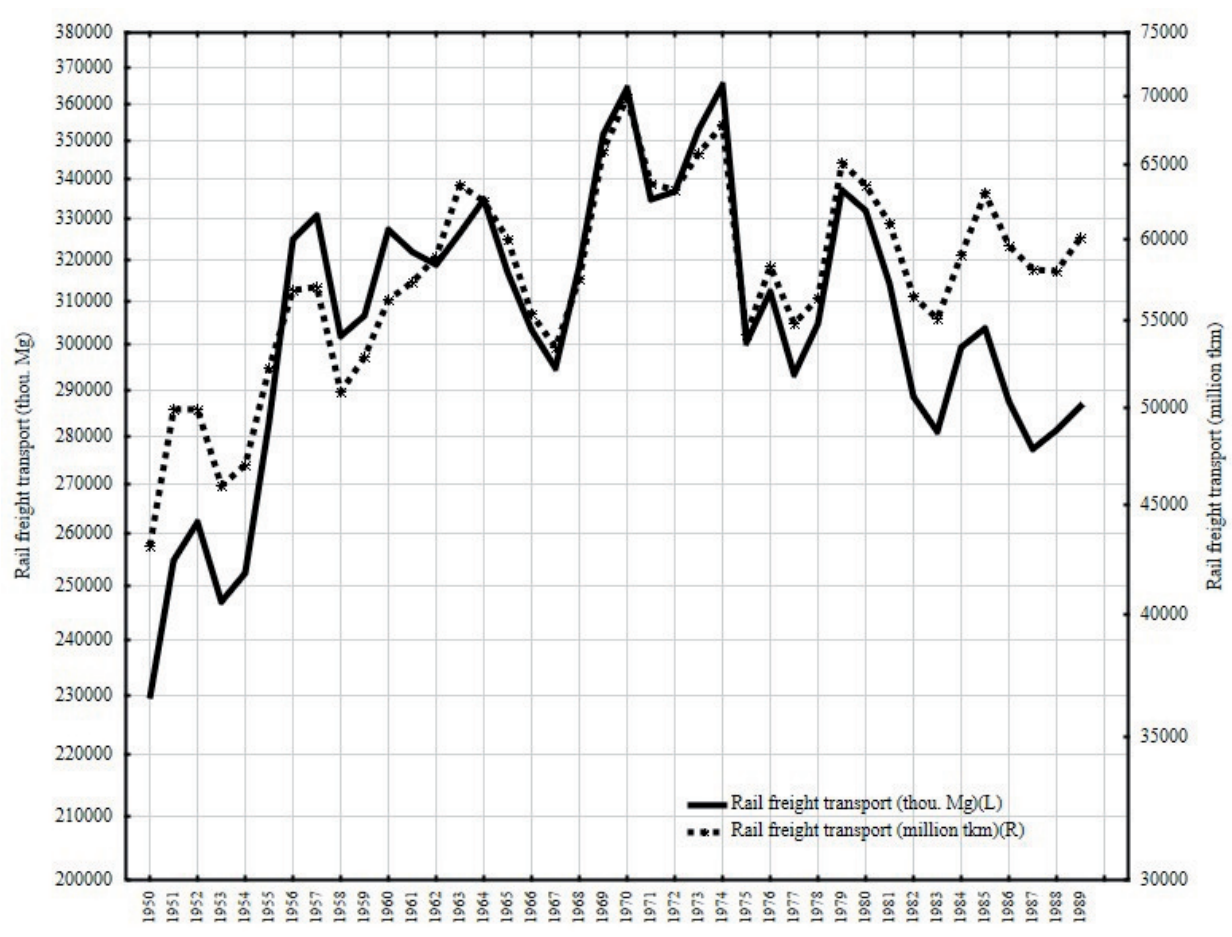

Figure 3. Rail freight transport (million tkm and thousand Mg) (1950-1989) Source: own study based on: Fremdling R. et. al. [1995].

cles, determined by changes in the GDP volume. The "bottom line“ of this activity took place in 1967, 1975 and 1982 [Kamińska K. 2018: 203].

In the seventies there was a clear slowdown in the average annual GDP growth rate to the level of $2.7 \%$, and GDP per capita to $2.3 \%$. GDP in constant prices in 1980 amounted to over 2 trillion DM (in 1970 - 1.54 trillion DM), while GDP per capita amounted to 74.8 thousand. DM against 58.1 thous. DM.

In the last analyzed period (1980-1989), the average annual GDP growth rate dropped significantly and amounted to about $1.9 \%$, while GDP per capita fell to about $1.6 \%$. The development trends in the German rail transport are illustrated in Figures 3 and 4.

Both rail freight transport, expressed in million $\mathrm{tkm}$ and million $\mathrm{Mg}$, fluctuated considerably and, respectively, in the analyzed period, it increased on an annual average by $0.5 \%$ and $0.2 \%$. However, in the last analyzed decade (1979-1989), rail freight transport decreased by $1.1 \%$ and 


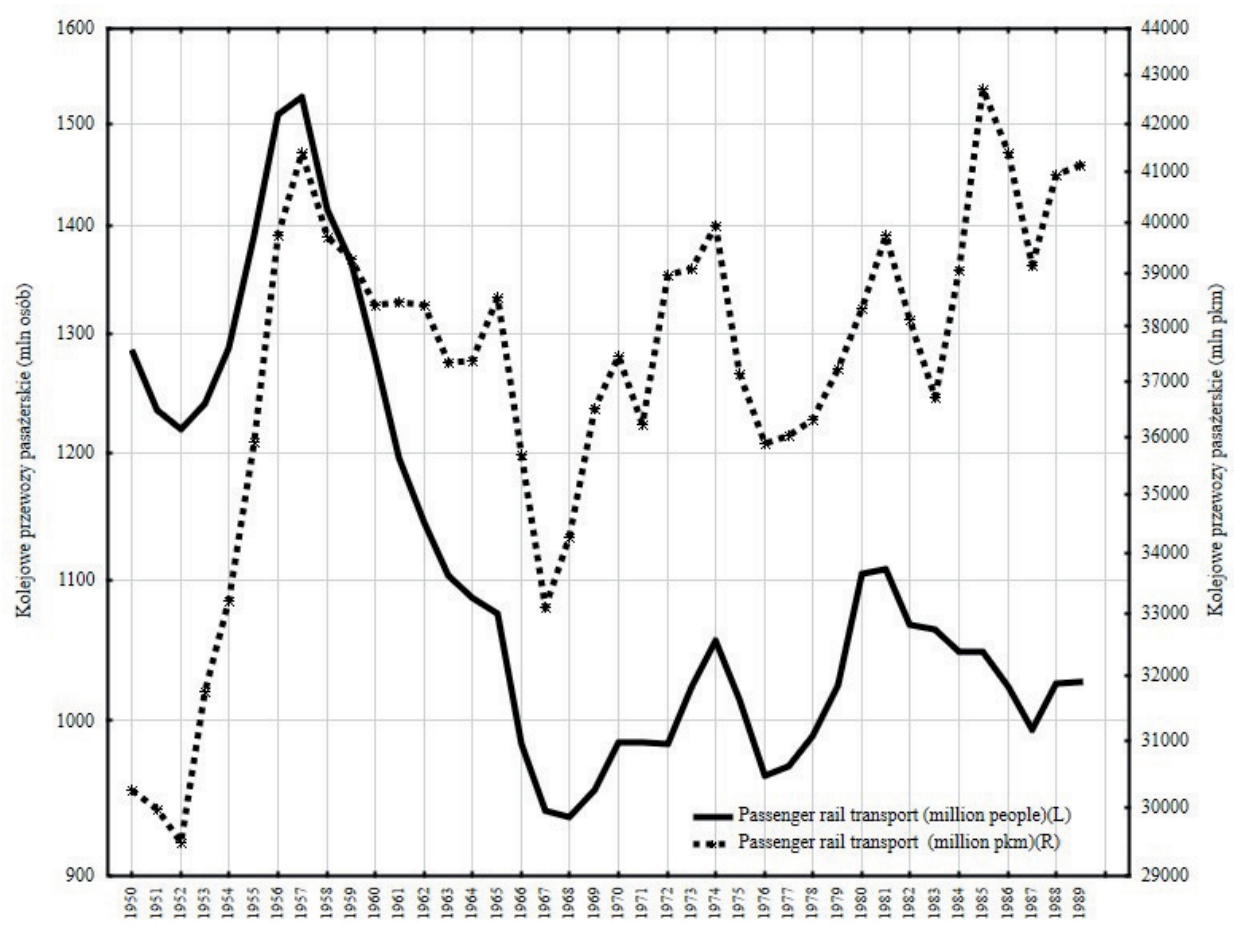

Figure 4. Passenger rail transport (million people, million pkm) (1950-1989)

Source: own study based on: Fremdling R. [1995].

$1.5 \%$, respectively. In the period 1950-1989, the average distance of rail freight transport was $132 \mathrm{~km}$ (1950), $117 \mathrm{~km}$ (1960) and $107 \mathrm{~km}$ (1970), while in 1989 it was $144 \mathrm{~km}$. Rail passenger transport (pkm) achieved an average annual growth rate of $0.44 \%$, and in the period 1979-1989 it grew on average by $1.1 \%$.

In the next stage, the degree of integration of the studied time series was analyzed using the extended Dickey-Fuller (ADF) test. It was assumed that the level of the tested significance $\alpha=5 \%$.

In the augmented Dickey-Fuller test (ADF), the $\mathrm{H} 0$ hypothesis assumes that the series is non-stationary. Therefore, if the probability of type (p) error I is greater than 5\%, $\mathrm{H} 0$ cannot be rejected, which gives rise to the inference that the time series is non-stationary.

Table 1 presents the results of the ADF test for the examined variables. They show that (except for the variables 1_RP_pkm and 1_Ex) all analyzed time series are non-stationary. At the significance level of $a=5 \%$, there 
were no grounds to reject the $\mathrm{H} 0$ hypothesis. Hence, the author examined the test results for the first differences.

The time series for the first differences for all variables are stationary, which gives rise to the conclusion that, apart from two cases, the remaining variables weree integrated I(1).

Table 1. Unit root test results (ADF test)

\begin{tabular}{|l|c|c|c|}
\hline \multicolumn{1}{|c|}{ Variable } & $\begin{array}{c}\text { ADF test for the tested } \\
\text { variables }(p \text { value })\end{array}$ & $\begin{array}{c}\text { ADF test of the first } \\
\text { differences }((p \text { value }))\end{array}$ & Conclusion \\
\hline L_RP_PKM & 0,0458 & $8,798 \mathrm{e}-005$ & $\mathrm{I}(0)$ \\
L_RF_Mg & 0,5137 & $1,257 \mathrm{e}-006$ & $\mathrm{I}(1)$ \\
L_RF_tkm & 0,0814 & $1,093 \mathrm{e}-005$ & $\mathrm{I}(1)$ \\
L_CF_Mg* & 0,4552 & $5,057 \mathrm{e}-005$ & $\mathrm{I}(1)$ \\
L_GDP_C & 0,1625 & 0,00126 & $\mathrm{I}(1)$ \\
L_GDP_PK_C & 0,9773 & $6,455 \mathrm{e}-006$ & $\mathrm{I}(1)$ \\
L_Ex & 0,0013 & $6,762 \mathrm{e}-007$ & $\mathrm{I}(0)$ \\
\hline
\end{tabular}

* for period: 1954-1989

Source: own study.

Usually, the degree of integration of the variables is subject to a parallel critical evaluation by the test of the inverse hypothesis; hence the author used the KPSS test. The results are presented in Table 2. In the KPSS test, the $\mathrm{H} 0$ hypothesis assumes that the series is stationary. If the statistic of this test is greater than the critical value for the significance level $\alpha=5 \%$ assumed by the author, then there are grounds to reject $\mathrm{H} 0$, i.e. the conclusion that the time series is non-stationary.

The unit root studies carried out using the ADF and KPSS tests proved that both the variables concerning the economic growth of Germany (GDP and GDP per capita), rail freight (tkm) and (Mg) were non-stationary series. Doubts were raised by the following variables: L_Ex and the L_CF_Mg variable. In view of the different test results, the author assumed that these variables are integrated I(1). However, the analysis of the 1_RP_ PKM variable was abandoned because it was integrated $I(0)$, which excludes it from the cointegration study. All other analyzed series are integrated I(1) (for $a=0.05)$.

The identical degree of integration of the analyzed time series allowed the author to carry out the Granger causality test. In this test, $\mathrm{H} 0$ assumes 
Table 2. The KPSS test for checking the unit root for variables ( $p$ value)

\begin{tabular}{|l|c|c|c|}
\hline \multicolumn{1}{|c|}{ Variable } & $\begin{array}{c}\text { KPSS test for the } \\
\text { tested variables }\end{array}$ & $\begin{array}{c}\text { KPSS test of the first } \\
\text { difference }\end{array}$ & Conclusion \\
\hline \multicolumn{3}{|c|}{ Critical value $(\mathrm{a}=5 \%)=0.149$} \\
\hline L_RP_PKM & 0.10595 & 0.07293 & $\mathrm{I}(0)$ \\
L_RF_Mg & 0.27904 & 0.04383 & $\mathrm{I}(1)$ \\
L_RF_TKM & 0.23900 & 0.03698 & $\mathrm{I}(1)$ \\
L_CF_Mg* & 1.17357 & 0.07680 & $\mathrm{I}(2)$ \\
L_GDP_C & 0.35014 & 0.12681 & $\mathrm{I}(1)$ \\
L_GDP_PK_C & 0.35481 & 0.04845 & $\mathrm{I}(1)$ \\
L_Ex & 0.23706 & 0.12017 & $\mathrm{I}(1)$ \\
\hline
\end{tabular}

* for period: 1954-1989

Source: own study.

that the causal variable does not affect the response variable. The hypothesis is rejected when the probability $(p)$ of making a Type I error is less than 0.05 .

According to the cointegration method described by R. Engle and C. Granger, in the first stage, the regression equation of a given variable with respect to the second variable had to be estimated using the OLS and the significance of the estimated parameters of the equation should be tested. In the second stage, it was necessary to determine the regression residuals and use the unit root test, eg ADF, to determine their stationarity. In the event that the ADF test shows that the rest of the model are stationary, then this vector will be a cointegrating vector [Engle R.F. Granger C.W.J. 1987: 251-76]. The calculation results for each pair are presented in Table 3.

Based on the Engle-Granger causality tests for individual pairs of variables, only the long-term unidirectional interaction was confirmed:

a) 1_GDP_C was the cause for 1_RF_TKM (line 2), but 1_RF_TKM was not the cause for 1_GDP_C.

b) 1_GDP_C was the cause for 1_RF_Mg (line 4), but 1_RF_Mg was not the cause for 1_GDP_C.

c) L_GDP_C was the cause for L_Ex (line 6), but 1_Ex was not the cause for 1_GDP_C.

d) 1_GDP_PC was the cause for 1_RF_TKM (line 10), but 1_RF_TKM was not the cause for 1_GDP_PC; 


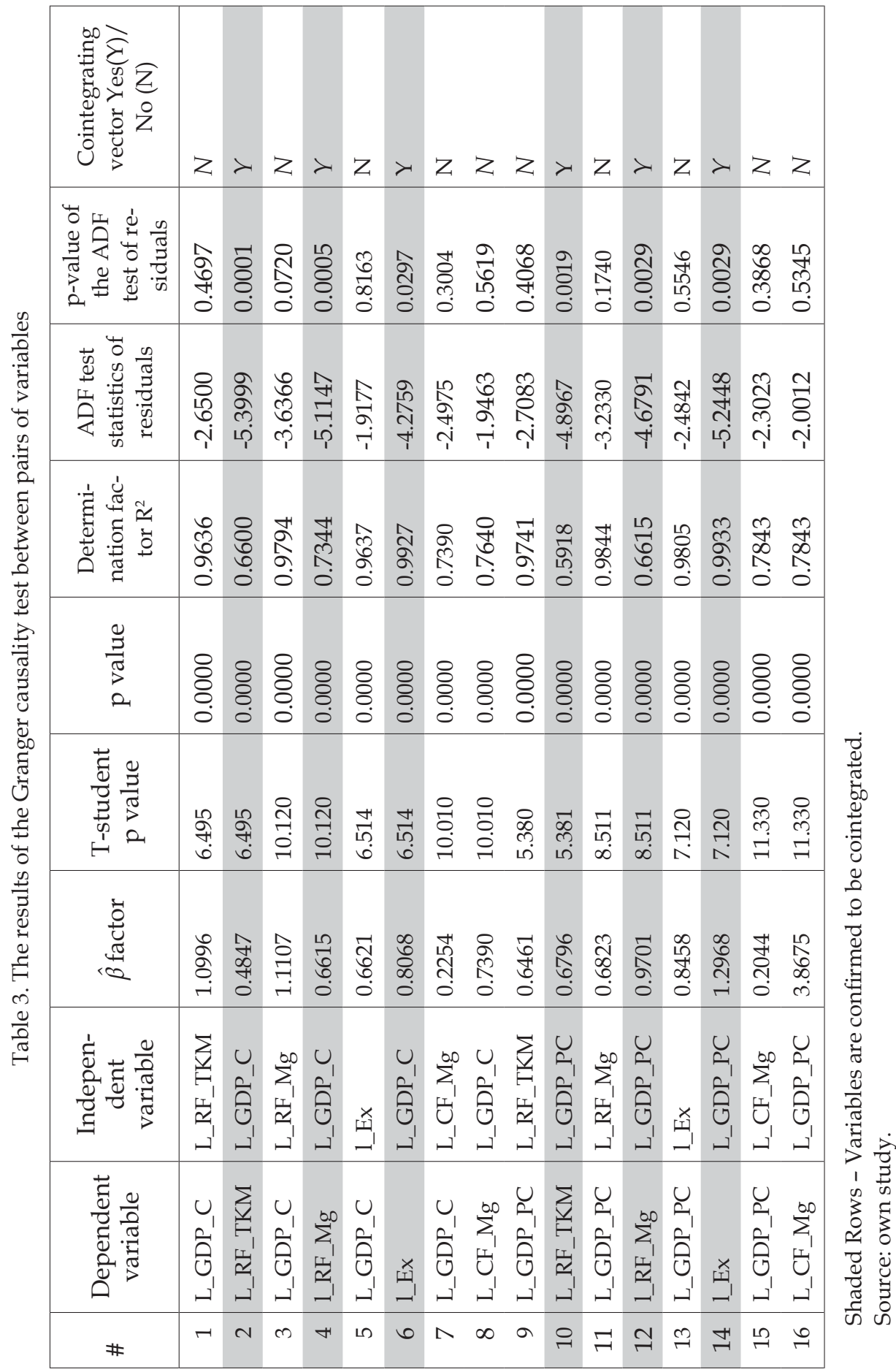


e) L_GDP_PC was the cause for 1_RF_Mg (line 12) but 1_RF_Mg was not the cause for L_GDP_PC;

f) L_GDP_PC was the cause for 1_Ex (line 14), but 1_Ex was not the cause for L_GDP_PC;

The long-term relationship (for equations 1,3,5,7-9,11,13,15-16) was not confirmed, which does not exclude that the variables interacted in a short period of time. Also, no long-term bi-directional relationships were found.

The research results show that economic growth (GDP and GDP per capita) had a positive impact on rail freight (in tkm and $\mathrm{Mg}$ ) and on the level of exports. This can be justified by the fact that the high rate of economic growth determined the development of transport infrastructure. On the other hand, the variables of GDP and GDP per capita were not the cause for the variable: road freight transport $(\mathrm{Mg})$, although these were analyzed in the period 1954-1989.

According to Granger's representation theorem, if the variables Yy and $\mathrm{Xt}$ are first degree integrated I(1) and are cointegrated, then the relationship between them can be presented as a vector error correction model (VECM) and impulse response which will be the subject of further research by the author.

\section{CONCLUSIONS}

The Federal Republic of Germany, despite the difficult socio-economic situation after the end of World War II and the division of the former territory of the Third Reich into four zones of occupation, achieved an unexpected economic success. The German Wirtschaftswunder not only contributed to the multiplication of social welfare, but it can also be considered a symbolic introduction to a new beginning [Commun P. 2004: 9]. Germany had to redefine its foreign trade policy and its place in Europe and in the world, taking into account the policy of the new order defined by the victorious powers. The currency reform, the independence of the central bank from the government, activity in the labor market, the Marshall Plan, and the restoration of economic potential were important factors in the German economic miracle. The concepts behind this success, however, vary.

The more research carried out by the author can be used as an attempt to search for causes using econometric modeling. 
The cointegration method of R. Engle and C. Granger, although simple, can give measurable results in establishing long-term interrelationships between the analyzed time series for economic variables, usually non-stationary.

The author, after establishing (ADF and KPSS tests) that the analyzed variables were essentially first-order I(I), used them for further research using the two-stage Engle-Granger test.

The research proved that in the analyzed period there was a long-term one-way relationship between economic growth (GDP, GDP per capita) and rail freight transport, expressed both in tkm and $\mathrm{Mg}$ - the development of transport was positively influenced by GDP and GDP per capita. On the other hand, no correlation in the opposite direction was noted, i.e. the impact of rail freight transport on the economic growth of Germany, and the long-term relationship between economic growth and the volume of freight transport using road transport was also not confirmed.

Taking these results into account, it is possible to confirm the validity of the claim that the railway industry did not play such a great role in shaping the modern economy and increasing the social welfare of Germany as in the previous periods [Myszczyszyn, 2019].

The dominant position in transport was occupied by road transport and sea transport. Air transport also joined the fight, although the longterm interdependence was not confirmed in the case of road transport and economic growth.

The above research confirms that it was Germany's economic growth rate that was an important factor determining the long-term development of transport. The results of the research confirm the hypothesis about the long-term interdependence of some time series of the variables under consideration, being at the same time the starting point for further research with the use of a larger number of exogenous variables and the use of VECM modeling.

At the same time, it is worth noting that the research using the Johanssen test (in the period 1954-1989) confirmed not only a uni-directional longrun relationship, but also bi-directional long-run relationship (e.g. GDP per capita and rail and road freight), which prompts the author to conduct further research on this range, including an attempt to estimate autoregressive short- and long-term models [Myszczyszyn J. et al. 2021].

It should be added that railway is still an important element in the German transport system, and its share in total freight transport in the last 
decade was $17-19 \%$ and over $9 \%$ in passenger transport (2019). Although road transport is dominant, the restoration of the railway can be observed.

Regardless of the results obtained, placing the research on the ground of theoretical assumptions in conjunction with the application of the presented methodological solutions fits in the still not very popular paradigm of the new economic history and may be an inspiration for other researchers.

In order to continue further research, the author formulated the following research postulates:

- expansion of transport development research to include data from the German Democratic Republic (GDR);

- the use of ARDL modeling (the autoregressive distributed lag) to determine the nature of dependencies in the long and short term;

- the use of autoregressive modeling of VAR (for a short period) and VECM (for a long period) as well as an impulse response function and IRF (Impulse Response Function), which will allow to determine the direction of the impact of variables regarding economic growth and development, types of transport, etc. GDR.

- a detailed overview of the transport policy in Germany and the

\section{REFERENCES}

Abelshauser W. (1981a), Wiederaufbau vor dem Marshallplan. Westeuropas Wachstumschancen und die Wirtschaftsordnungspolitik in der zweiten Hälfte der vierziger Jahre, Vierteljahrshefte für Zeitgeschichte, 29, 545-578.

Abelshauser W. (1981b), Wirtschaft in Westdeutschland 1945-1948. Rekonstruktion und Wachstumsbedingungen in der amerikanischen und britischen Zone, Stuttgart 1975; ders., Wiederaufbau vor dem Marshallplan. Westeuropas Wachstumschancen und die Wirtschaftsordnungspolitik in der zweiten Hälfte der vierziger Jahre, in: VfZ 29, 545 578; ders.,Hilfe und Selbsthilfe. Zur Funktion des Marshallplans beim westdeutschen Wiederaufbau, in: VfZ 37(1989), 85-113.

Abelshauser W. (2011), Deutsche Wirtschaftsgeschichte seit 1945 bis zu Gegenwart, CH Beck, München.

Abramovitz M. (1986), Catching Up, Forging Ahead, and Falling Befund, Journal of Economic History, 46, 385-406.

Aschauer D.A. (1989), Is public expenditure productive?, Journal of Monetary Economics, 23(2), 177-200.

Bardt H., Chrischilles E., Fritsch M., Grömling M., Puls T., Röhl K.-H. (2014), Die Infrastruktur in Deutschland. Zwischen Standortvorteil und Investitionsbedarf. Institut der deutschen Wirtschaft Köln, Wyd. Hundt Druck GmbH, Köln. 
Baumgart E.R. (1961), Investitionen und ERP-Finanzierung, DIW Sonderhefte, 56, Duncker \& Humblot, Berlin.

Hartwig K .H., Holznagel B., Ströbele W., Suntum U. (2008), Bedeutung der Infrastrukturen im internationalen Standortwettbewerb und ihre Lage in Deutschland, Netzindustrien im 21. Jahrhundert, Lebensqualität, Sicherheit, , Bundesverbandes der Deutschen Industrie (BDI), Wohlstand, https://bdi.eu/media/presse/publikationen/Publikation_BDIInfrastruktur-Konferenz_2008.pdf, accessed 27.07.2021.

Berger H., Ritschl A. (1995), Die Rekonstruktion Der Arbeitsteilung i Europa, Eine neue Sicht des Marshallplans in Deutschland 1947-1951, Vierteljahrhefte Für Geschichte, 43, Heft 3.

Berghahn V. (1984), Ideas into Politics: The Case of Ludwig Erhard [in:] Bullen R.J. Strandmann von H.P., Polonsky A.B. (eds.), Ideas into Politics: Aspects of European History 1880-1950, Croom Helm, London.

Beyzatlar M. A., Karacal M, Yetkiner I. H. (2012), Granger-causality between Transportation and GDP: A Panel Data Approach, Working Papers in Economics, 12(03), 1-17.

Bom P.R.D., Ligthart J.E. (2008), How Productive is Public Capital? A Meta-Analysis, CESifo Working Paper, 2206, München.

Borchardt K. (1976), Wachstum und Wechsellagen 1914/1970 [in:] Aubin H., Zorn W. (eds), Handbuch der deutschen Wirtschafts- und Sozialgeschichte, Klett-Cotta, Stuttgart.

Borchardt K., Buchheim Ch. (1987), Die Wirkung der Marshallplan-Hilfe in Schlüsselbranchen der deutschen Wirtschaft, in: VfZ 35, 317-347

Busch B., Klös H.P. (1995), Potentialfaktor Infrastruktur, Ökonomische Bedeutung und privatwirtschaftliches Engagement, Beiträge zur Wirtschafts- und Sozialpolitik, Nr. 222, Köln.

Buchheim C. (1990), Die Wiedereingliederung Westdeutschlands in die Weltwirtschaft 19451958, R. Oldenbourg Vlg., München.

Commun P. (2004), Erhards Bekehrung zum Ordoliberalismus: Die grundlegende Bedeutung des wirtschaftspolitischen Diskurses in Umbruchszeiten, Freiburger Diskussionspapiere zur Ordnungsökonomik, 04/4, 9, Walter-Eucken-Inst., Freiburg im Breisgau.

Cullison W. E. (1993), Public Investment and Economic Growth, Federal Reserve Bank of Richmond Economic Quarterly, 79(4), 19-34.

Deutsches Geld- und Bankwesen in Zahlen 1876-1975 (1976), Wyd. Deutsche Bundesbank, Frankfurt/M.

Dickey D.A., Fuller W. (1979), Distribution of the estimators for autoregressive time series with a unit root, Journal of the American Statistical Association, 74, 427-431.

Dumke R. (1990), Reassessing the Wirtschaftswunder: Reconstruction and Postwar Growth in West Germany in an International Context, Oxford Bulletin of Economies and Statistics, $52,451-491$.

Eichengreen B., Ritschl A. (2008), Understanding West German Economic Growth in the 1950s, SFB 649, Discussion Paper 2008/068, Humboldt University of Berlin, Collaborative Research Center 649 - Economic Risk, Berlin, Microsoft Word - Frontpage 068.doc (econstor.eu), accessed 27.07.2021.

Enders W. (2010), Applied Econometric Time Series, Willey, New York.

Engle R.F., Granger C.W.J. (1987), Co-Integration and Error Correction: Representation, Estimation, and Testing, Econometrica, 55(2), 251-276.

Fedderke J.W., Perkins P., Luiz J.M. (2006), Infrastructural Investment in Long-run Economic Growth: South Africa 1875-2001, World Development, 34(6), 1037-1059.

Fremdling R., Federspiel R., Kunz A. (1995), Statistik der Eisenbahnen in Deutschland 1835 - 1989. Bearbeitet von Ruth Federspiel, unter Mitarbeit von Dietlind Hüchtker und Angelus Johansen, Scripta Mercaturae Verlag, St. Katharinen. 
Groote, P., Jacobs, J. and Sturm, J. E. (1999), Output Effects of Transport Infrastructure: The Netherlands, 1853-1913, Tijdschrift voor Economische en Sociale Geografie, 90(1), 97-109.

Gimbel J. (1976), The Origins of the Marshall Plan, Stanford University Press, Stanford.

Granger C.W.J. (1981), Some Properties of Time Series Data of Their Use in Econometric Model Specification, Journal of Econometrics, 67, 173-188.

Harizi R., M'raïhi R. (2014), What We Learned about the Relationship between Transport System, Economic and Population Growth in the case of Landlocked Country?, Journal of Economic and Financial Modelling, 2(1), 55-67.

Jánossy F. (1966), Das Ende der Wirtschaftswunder, Verl. Neue Kritik, Frankfurt/M.

Johansen S. (1988), Statistical Analysis of Cointegration Vectors, Journal of Economic Dynamics and Control, 12, 231-254.

Kamińska K. (2018), Ordoliberalizm i keynesizm - dwie sprzeczne koncepcje w polityce gospodarczej powojennych Niemiec, Urząd Ochrony Konkurencji i Konsumentów, Warszawa.

Knapp M. (1977), Deutschland und der Marshallplan: Zum Verhältnis zwischen politischer und ökonomischer Stabilisierung in der amerikanischen Deutschlandpolitik nach 1945, [in:] Scharf C., Schröder H.-J. (eds.), Politische und ökonomische Stabilisierung Westdeutschlands 19451949, Franz Steiner, Wiesbaden, 19-43.

KnieA.(2007),ErgebnisseundProblemesozialwissenschaftlicherMobilitäts-und Verkehrsforschung (in:) Schöller, O., Canzler, W., Knie, A. (eds.), Handbuch Verkehrspolitik, Springer, Wiesbaden, 43-60.

Kulshreshtha M., Nag B., Kulshreshtha M. (2001), A Multivariate Cointegrating Vector Auto Regressive Model of Freight Transport Demand: Evidence from Indian Railways. Transportation Research Part A: Policy and Practice, 35(1), 29-45.

Kusideł E. (2001), Modelowanie wektorowo-autoregresyjne VAR. Metodologia i zastosowanie w badaniach ekonomicznych, Wydawnictwo Absolwent, Łódź.

Li F., Song Z., Liu W. (2014), China's Energy Consumption under the Global Economic Crisis: Decomposition and Sectoral Analysis, Energy Policy, 64, 193-202.

Maddala G.S. (2006), Ekonometria. Wydawnictwo Naukowe PWN, Warszawa.

Marona B., Bieniek A. (2013), Wykorzystanie modelu VECM do analizy wpływu bezpośrednich inwestycji zagranicznych na Gospodarkę Polski w latach 1996-2010, Acta Universitatis Nicolai Copernici, Ekonomia, XLIV, 2, 333-350.

McAdam P. (1998), A pedagogical note on the long run of macroeconomic models, University of Kent, Kent.

Milward A.S. (1984), The Reconstruction of Western Europe, 1945-1951, Methuen, London

Mill J.S. (1924), Grundsätze der Politischen Ökonomie (1848, 7. Aufl. 1871), 2, G. Fischer, Jena.

Myszczyszyn J. (2013), Wptyw kolei żelaznych na wzrost gospodarczy Niemiec 1850-1913, Wydawnictwo Uniwersytetu Łódzkiego, Łódź.

Myszczyszyn J. (2019), Wykorzystanie analizy kliometrycznej w ocenie wptywu kolei żelaznych na wzrost gospodarczy Niemiec, Wyd. Zachodniopomorski Uniwersytet Technologiczny w Szczecinie, Szczecin.

Myszczyszyn J. (2020), The Long-run Relationships between Number of Patents and Economic Growth, European Research Studies Journal, Vol. XXIII, Issue 3, 2020, doi: $10.35808 / \mathrm{ersj} / 1654$.

Myszczyszyn J., Mickiewicz B., Mickiewicz P. (2021), Analysis of Correlation Between the Economic Growth and Transport Development (1954-1989) [in:] Innovation Management and information Technology impact on Global Economy in the Era of Pandemic, The 37th International Business Information Management Association Conference (IBIMA), 91-98. 
Nicholls A.J. (1990), Ludwig Erhard and German Liberalism - An ambivalent Relationship? [in:] Jarausch K., Jones L.E. (eds.), In Search of liberal Germany: Studies in the History of German Liberalism from 1789 to the present, Berg, Oxford.

Rostow W.W. (1960), The stages of economic growth: A non-communist manifesto, New York, Cambridge University Press.

Röpke W. (1945), Die deutsche Frage, E. Rentsch, Erlenbach Zürich.

Shafique M., Azam A., Rafiq M., Luo X. (2020), Evaluating the Relationship between Freight Transport, Economic Prosperity, Urbanization, and CO2 Emissions: Evidence from Hong Kong, Singapore, and South Korea, Sustainability, 12(24), 10664, doi:10.3390/ su122410664.

Spahn H.P. (1991), Das erste und das zweite deutsche Wirtschaftswunder, Wirtschaftsdienst, Verlag Weltarchiv, Hamburg, 71(2): 73-79.

Statistisches Jahrbuch für die Bundesrepublik Deutschland 1998 (1999), Statistisches Bundesamt Wiesbaden (Hrsg.), Metzler-Poeschel, Stuttgart.

Skodlarski J. (2012), Historia gospodarcza, PWN, Warszawa.

Stadelbauer J. (1994). Räumliche Aspekte der Teilung und Vereinigung von Staatswesen. Eine politisch-geographische Überlegung unter Betonung der Infrastrukturentwicklung in der Bundesrepublik Deutschland [in:] Chong-Ko Tzou: Euro-Asia relations in transition in the post-cold war. Taipei, Taiwan: Graduate School of European Studies, Tamkang Univ. 60.

Suntum U., Hartwig K. H., Holznagel B., Ströbele W., Armbrecht H., Deckers S., Uhde N., Westermeier A. (2008), Bedeutung der Infrastrukturen iminternationalen Standortwettbewerb und ihre Lage in Deutschland, Gutachten im Auftrag des Bundesverbandes der Deutschen Industrie (BDI), Münster.

Ziegler D. (1996), Eisenbahnen und Staat im Zeitalter der Industrialisierung. Die Eisenbahnpolitik der Deutschen Staaten im Vergleich, VSAG Beiheft e 127, Franz Steiner Verlag, Stuttgart.

Janusz Myszczyszyn, dr hab., is a professor at West Pomeranian University of Technology in Szczecin, affiliated with the Faculty of Economics, Department of Economics and Accounting. Research interests: economic history, numerical methods in economic history (cliometrics), economic growth and development, sustainable development, implementation of ERP systems. 